\title{
Immunological upgrading with combined immunotherapy and chemotherapy in a lepromatous leprosy patient: a case report
}

\author{
S A ZAHEER, ${ }^{*} \mathrm{~N}$ R SURESH, ${ }^{*} \mathrm{H}$ K KAR, $\dagger$ \\ A K SHARMA $\dagger$ A MUKHERJEE, $\ddagger$ R MUKHERJEE* \& \\ G P TALWAR* \\ * National Institute of Immunology, Jit Singh Marg, New Delhi 110 \\ 067, India; $\dagger$ Dr Ram Manohar Lohia Hospital, New Delhi; and \\ $\ddagger$ Institute of Pathölogy, ICMR, Safdarjang Hospital, New Delhi
}

Accepted for publication 29 March 1991

\begin{abstract}
Summary Immunotherapy with Mycobacterium $w$ was given, in addition to standard multidrug therapy (MDT) to a lepromatous leprosy (LL) patient with a bacteriological index (BI) of 6 . After 15 months of treatment this patient attained bacteriological negativity and clinical inactivity. Histopathologically the patient upgraded to borderline-tuberculoid at 12 months, and at 15 months showed features of nonspecific infiltration in the dermis. The rapid immunological upgrading seen in the patient is highlighted in this paper.
\end{abstract}

\section{Introduction}

Lepromatous leprosy patients show anergy to react against Mycobacterium leprae and its multiplication in skin and peripheral nerves is virtually unchecked as there is an absence of host cell-mediated immunity (CMI). ${ }^{1}$ This case report forms part of a large scale ongoing phase II/phase III clinical trials to evaluate the immunotherapeutic and immunoprophylactic potential of an antileprosy vaccine, Mycobacterium w (M.w). The study is designed to investigate if immunotherapy in the form of a vaccine, based on a cross-reactive mycobacterium, given as an adjunct to chemotherapy is able to induce host CMI and reverse the host anergy to $M$. leprae. Early results of the immunotherapeutic trials with this vaccine have already been reported. ${ }^{2,3}$ This case highlights a patient with an initial bacteriological index (BI) of 6 who upgraded immunologically to borderlinetuberculoid (BT) and then was completely cleared of bacilli and granuloma in a period of less than 24 pulses of MDT.

\section{Case report}

A 55-year-old male patient came with complaints of lesions on trunk and limbs, loss of sensation in hands and feet and a trophic ulcer on the left foot of 18 months duration. He 


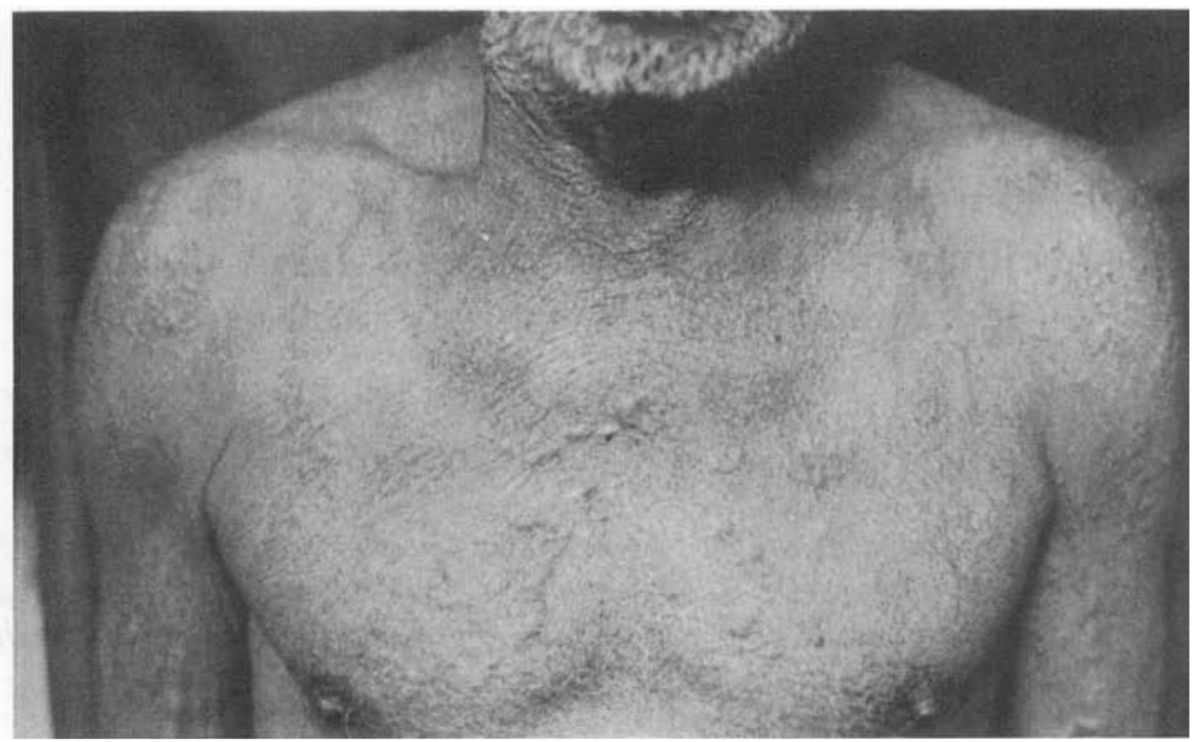

Figure 1. Erythematous papulonodular lesions over the chest.

had no previous history of treatment. On examination the patient had papulonodular lesions and erythematous plaques over the face, chest and back and coarse infiltration over the rest of the body (Figure 1). All nerve trunks were bilaterally involvedmoderately thick but not tender. The patient had glove and stocking loss of sensation. Slit smears from both eyebrows, earlobes and from two patches on the lower back gave a

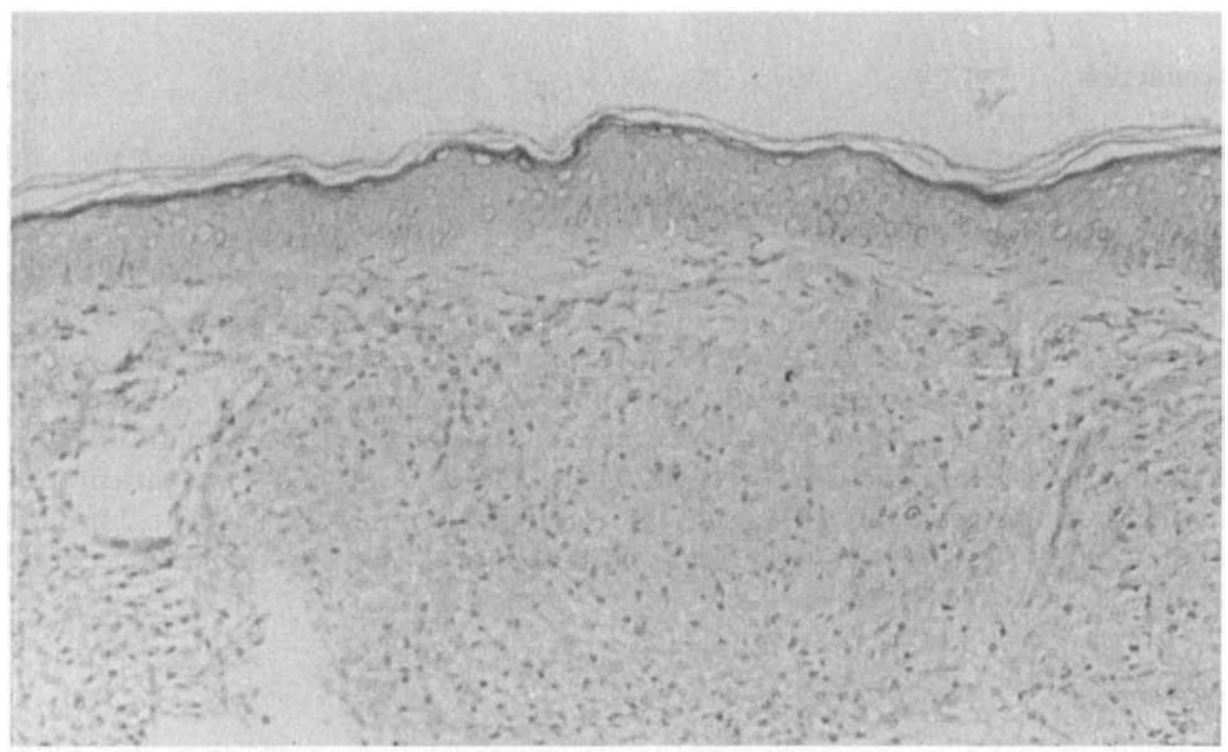

Figure 2. Photomicrograph showing macrophage granuloma in dermis with sparing of sub-epidermal zone. Lymphocytes are scanty and randomly distributed. This lesion had a BI of $5+$ on the Ridley scale. $(\mathrm{H} / \mathrm{E} \times 600)$ 
cumulative BI of 6 (Ridley's logarithmic scale). Clinical diagnosis of subpolar lepromatous leprosy was made. This was confirmed histopathologically (Figure 2). Lepromin A (supplied by WHO) testing was done. The late Mitsuda reaction at 21 days was negative.

Clinical scoring was done every 6 months using Ramu's score. ${ }^{4.5}$ In this scoring system the body is divided into 7 regions, i.e. face, head and neck, right and left upper limbs, chest and abdomen, back and buttock, and right and left lower limbs. Each region is independently scored. A score of one is given to predominantly macular lesions, two to diffuse infiltration, three to few papules or plaques and four to predominantly papulonodular lesions. A score of one to four is thus given to each of the 7 regions. This patients cumulative initial score was 22. The patient was administered a standard multidrug regimen $(\mathrm{MDT})^{6}$.

In addition to chemotherapy, the patient received vaccine containing $1 \times 10^{9} \mathrm{killed}$ $M . w$ in $0.1 \mathrm{ml}$ normal saline $(0 \cdot 85 \% \mathrm{NaCl})$ as first dose, followed by $5 \times 10^{8}$ killed bacilli as subsequent doses given intradermally (i.d.) at 3 monthly intervals. After 2 doses of vaccine and 4 months of regular treatment, the patient defaulted in attending the clinic due to personal problems. After a 7-month lapse, the patient reported to the clinic presenting with a mild Type 1 upgrading reaction. During this period the patient denied having taken any antileprosy treatment. The spot test for dapsone (DDS) ${ }^{7}$ in urine was negative. The patient was then reviewed for his clinical, bacteriological, histopathological and immunological status. The patients BI had fallen to $2 \cdot 33$, and he had histopathologically upgraded to BL. The lepromin reaction was $5 \mathrm{~mm}$ at this time and clinical improvement was evidenced by a decrease in clinical score to 15 . The patient was managed on nonsteroidal anti-inflammatory drugs (NSAID).

At the end of 12 months of treatment and 4 doses of vaccine, the patient showed notable clinical (Figure 3) and bacteriological improvement. His BI had fallen to 0.66 and his clinical score was 5. Histopathologically there was an upgrading to BT (Figure 4) and a

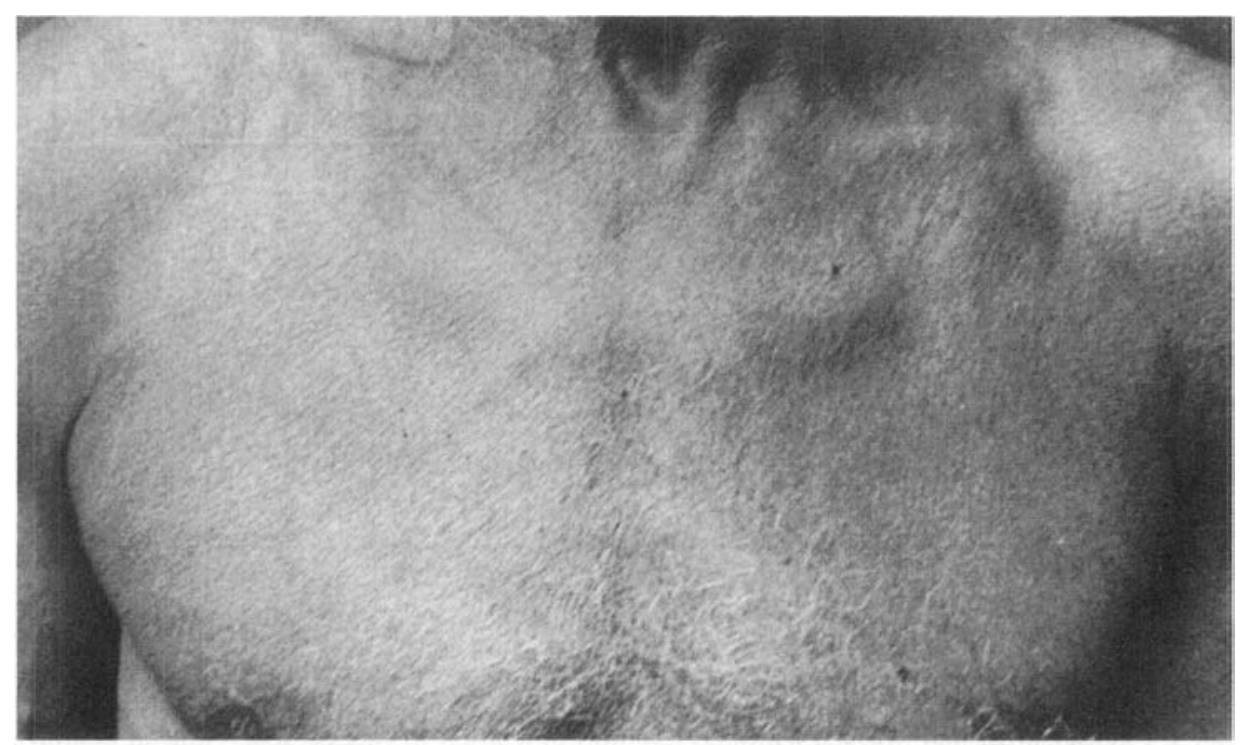

Figure 3. After 4 doses of Mycohacterium w vaccine, clearing of lesions is seen. 


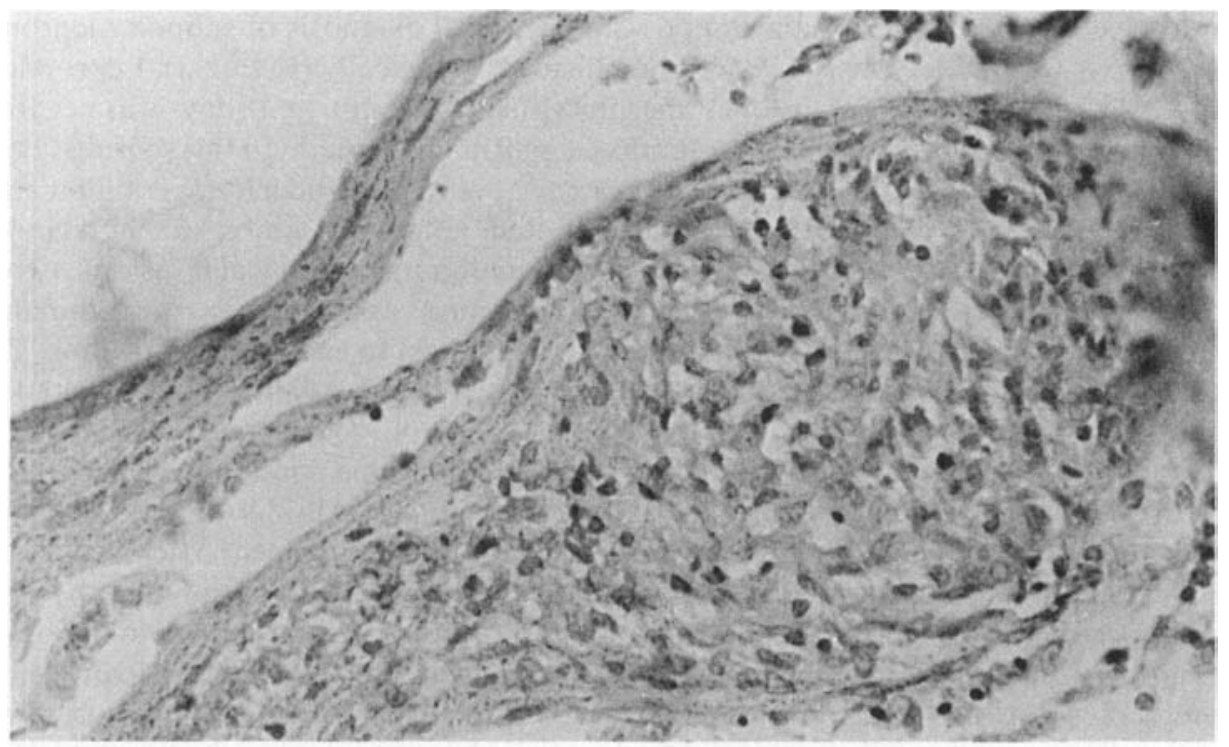

Figure 4. Photomicrograph from a biopsy taken at the end of 12 months treatment showing a small granuloma within the arrectores pilorum muscle. The cells comprising the granuloma were epithelioid cells, scattered lymphocytes and ill formed giant cells. This was the only granuloma seen in the entire section. No bacilli were found in the lesion at this stage. $(\mathrm{H} / \mathrm{E} \times 1320)$.

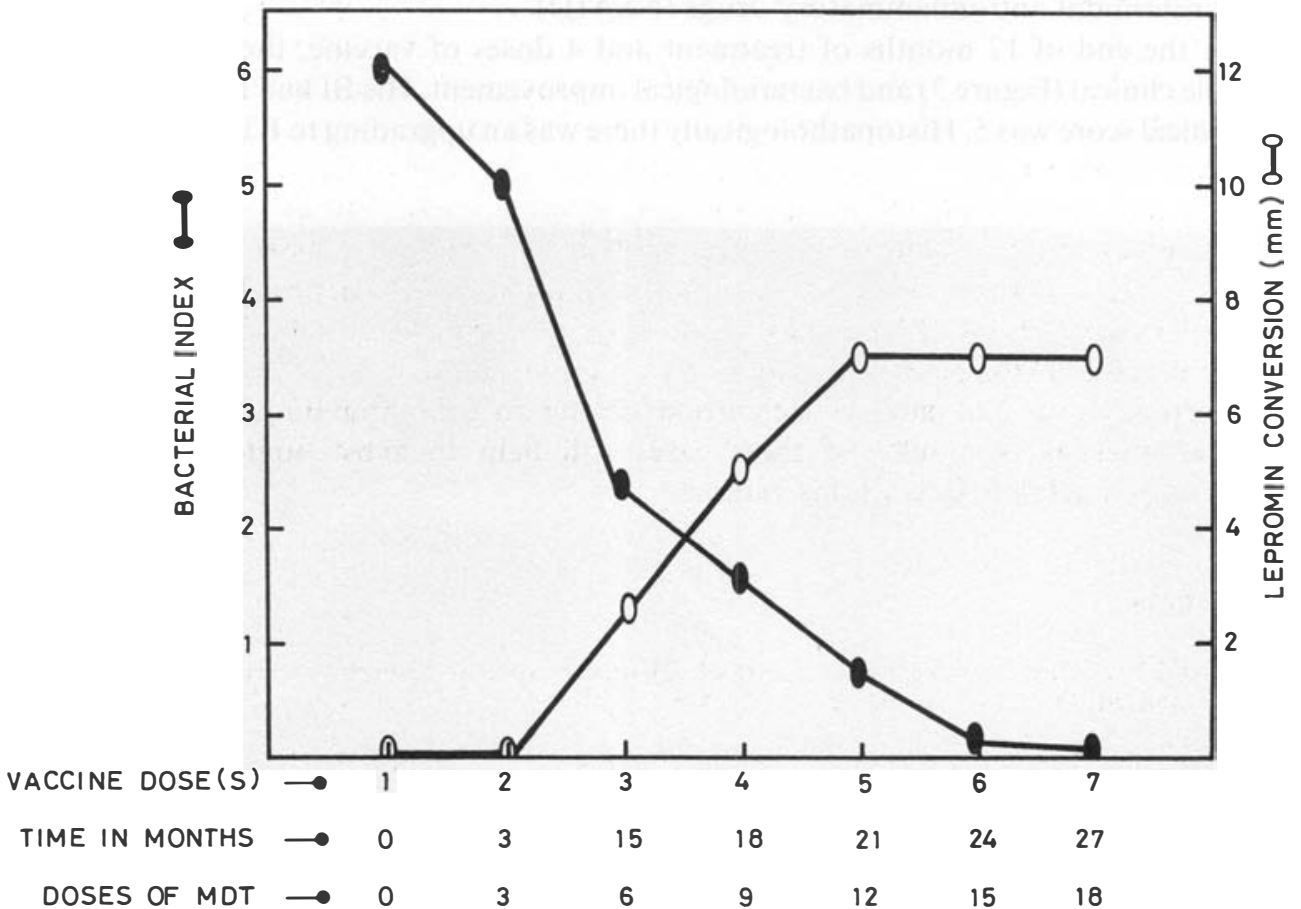

Figure 5. Changes in B I and Mitsuda lepromin reactions in relation to vaccine doses, time in months and treatment status. 
lepromin reaction showed $7 \mathrm{~mm}$ induration (moderately positive). After a further period of 3 months of therapy, the patient reached a stage of both bacterial and clinical inactivity. Biopsy from the same skin site revealed only sparse infiltration in the dermis with no evidence of granuloma or AFB. Repeat slit-skin smears over the next 2 months were also negative. In October 1989 this patient was released from treatment after completing 24 pulses. Case progression in terms of lepromin conversion and bacterial fall is given in Figure 5.

\section{Discussion}

This case report highlights the immunological upgrading of an LL patients after receiving M.w vaccine.

The reports with MDT alone show that in multibacillary (MB) cases, the mean BI fall is between 0.6 and 1.0 unit per year ${ }^{8}$. It is well documented that patients on chemotherapy do not upgrade immunologically and remain lepromin negative at the end of therapy despite bacteriological negativity. ${ }^{9,10}$

This particular case demonstrated a rapid fall in BI (from 6 to 0 in less than 24 months), showed a Mitsuda lepromin conversion (from negativity to $7 \mathrm{~mm}$ positivity) and went through a gradual histopathological upgrading from LL to BL to BT and then showed complete subsidence of disease without any undesirable side-effects including nerve damage. Convit et al. have reported immunological upgrading with a vaccine containing killed $M$. leprae and live BCG. They observed histological upgrading in $71 \%$ patients and soluble antigen (SA) conversion in $38 \%$ active LL and BL patients. ${ }^{11,12}$ Kaplan et al. have shown faster rates of BI fall in sites locally injected with interleukin-2. ${ }^{13}$ Deo et al. have used ICRC bacillus as a n immunotherapeutic vaccine. The vaccine has shown to engender lepromin conversion and clinical upgrading in lepromatous patients. ${ }^{14}$

The mechanisms of action of $M . w$ are as yet unclear. The in vitro and animal experimental studies indicate presence in $M . w$ of antigens cross-reactive with $M$. leprae. ${ }^{15,16}$ These antigens were found immunogenic in nature as they evoked DTH type of reaction in both LL and TT patients, when administered intradermally. ${ }^{17.18} M . w$ has also shown a good DTH response locally at the vaccination site.

Currently over 320 patients are enrolled in the on going immunotherapeutic trials. Further analysis of results of these cases will help to substantiate the beneficial immunotherapeutic effects of this vaccine.

\section{References}

1 Godal T, Myklestad, B, Tameul DR, Myrvang B. Characterization of cellular immune def ect in lepromatous leprosy: a specific lack of circulating Mycobacterium leprae-reactive lymphocytes. Clin exp. Imm, 1971; 9: $821-31$.

2 Talwar GP, Zaheer SA, Mukherjee R, Walia R, Misra RS, Sharma AK, Kar HK, Mukher jee A, Parida SK, Suresh NR, Nair SK, Pandey RM. Immunotherapeutic effects of a vaccine based on a saprophytic cultivable mycobacterium, Mycobacterium $w$ in multibacillary leprosy patients. Vaccine, 1990; 8: 121-9.

3 Talwar GP, Zaheer SA, Suresh NR, Parida SK, Mukherjee R, Singh IG, Sharma AK, Kar HK, Misra RS, Mukherjee A. Immunotherapeutic trials with a candidate antileprosy vaccine based on Mycobacterium w. Trop Med Parasitol, 1990; 41: Suppl. 2: 369-70.

4 Ramu G, Desikan KV. A follow up study of borderline tuberculoid leprosy under sulphone monotherapy. Ind J Lepr, 1988; 60: 26-33. 
${ }^{5}$ Iyer CGS, Balakrishnan S, Ramu G. A comparison of low and conventional dosages of dapsone in the treatment of lepromatous leprosy in India. Lepr Ind, 1977; 49: 372-88.

${ }^{6}$ WHO Study Group. Chemotherapy of leprosy for control programmes. Technical Report Series No. 675. WHO: Geneva, 1982.

${ }^{7}$ Naik SS, Sahasrabudhe RV. Comparative study of different drug compliance tests available in leprosy. Ind $J$ Lepr, 1988; 60: 270-6.

${ }^{8}$ Grosset JH. Recent developments in the field of multidrug therapy and future research in chemotherapy of leprosy. Lepr Rev, 1986; 57 (Suppl. 3): 223-34.

9 Nath I. Immunological aspects of human leprosy. Lepr India, 1983; 55: 752-62.

${ }^{10}$ Esquenazi DA, Sampaio EP, Moreira AL, Gallo MEN, Almeida SMR, Sarno EN. Effect of treatment on immune responsiveness in lepromatous leprosy patients. Lepr Rev, 1990; 61: 251-7.

"Convit J, Aranzazu N, Ulrich M, Pinardi ME, Reyes O, Alvarado J. Immunotherapy with a mixture of Mycobacterium leprae and BCG in different forms of leprosy and in Mitsuda negative contacts. Int J Lepr, 1982; 50: 415-24.

12 Convit J, Aranzazu N, Pinardi ME, Ulrich M. Immunological changes observed in indeterminate and lepromatous leprosy patients and Mitsuda negative contacts af ter inoculation of a mixture of Mycobacterium leprae and BCG. Clin exp Imm, 1979; 36: 214-20.

13 Kaplan G, Kiessling R, Sabawork T, Hancock G, Sheftel G, Job CK, Converse P, Ottenhoff TMH, BecxBleumink M, Dietz M, Cohn Z. The reconstitution of cell mediated immunity in the cutaneous lesions of lepromatous leprosy by recombinant interleukin-2. J. exp Med, 1989; 169: 893-907.

14 Deo MG, Bapat CV, Bhalerao V, Chaturvedi RM, Chulawala RG, Bhatki WS, Anti-leprosy potentials of the ICRC vaccine: a study in patients and healthy volunteers. Int $J$ Lepr, 1983; 51: 540-9.

15 Ganju L, Mukherjee R, Batra HV, Talwar GP. Immunoblot analysis of antigens of Mycobacterium w: A candidate antileprosy vaccine using monoclonal antibodies and patients sera. Int J Microbiology, 1990; 273: 378-85.

16 Mustafa AS. Identification of T cell activating recombinant antigens shared among three candidate anti leprosy vaccines, killed M. leprae, M. bovis BCG and Mycobacterium w. Int J Lepr, 1988; 56: 265-70.

17 Mustafa AS, Talwar GP. Early and late reactions in tuberculoid and lepromatous leprosy patients with lepromin from M. leprae and five selected cultivable mycobacteria. Lepr India, 1978; 50: 566-71.

18 Girdhar BK, Desikan K V. Results of skin tests with five different mycobacteria. Lepr India, 1978; 50: 555-9.

\title{
Amélioration de l'immunité suite à une immunothérapie combinée à une chimiothér- apie chez les patients LL: une observation
}

\author{
S A Zaheer, N R Suresh, H K Kar, A K Sharma, A Mukherjee, \\ R MuKherJeE ET G P TALWAR
}

Résumé Un patient lèpre lépromateuse (LL) dont le indíce bactériologique (BI) était de 6 a subi une immunothérapie au Hansen Mycobacterium w'à la suite d'un traitement par associations médicamenteuses. Après 15 mois de traitement, il y avait négativité des examens bactériologiques et absence de symptômes chez ce patient. Sur le plan histopathologique, le patient a progressé vers la tuberculö̈de dimorphe 12 mois, et à 15 mois, il présentait des caractéristiques d'infiltration dermique non-spécifique. L'amélioration rapide de l'immunité de ce patient est discutée dans le présent article.

\section{Mejoramiento inmunológico con inmunoterapia y quimioterapia combinada en un paciente LL: Informe de un caso}

\author{
S A Zaheer, N R Suresh, H K Kar, A K Sharma, A Mukherjee, \\ R MuKHERJEE Y G P TALWAR
}

Resumen A un paciente leproso lepromatoso ( $\mathrm{LL}$ ) con un indíce bacteriológico (BI) de 6, se le dió inmunoterapia con Mycobacterium w en adición a la terapia estándar de multidroga (MDT). Después de 15 meses de tratamiento, este paciente alcanzó negatividad bacteriológica e inactividad clínica. Este paciente mejoró histopatológicamente y llegó a estar sólo en el límite de la tuberculosis después a los 12 meses de tratamiento y a los 15 meses mostró signos de infiltración no-específica en la dermis. Se destaca en este trabajo el rápido mejoramiento inmunológico visto en el paciente. 